\title{
Psychological Peculiarities of the Preschool Age Children with Speech Violations
}

\author{
Mariya Komisaryk, Kateryna Kuznietsova
}

It is concluded that the study of the basics of speech therapy is necessary for all staff of preschool institutions in order to timely notice the language disorder of preschool children and quickly and efficiently overcome it. This will contribute to the better assimilation of knowledge by the child, the manifestation of his creative abilities, adaptation in society, optimization of mental development of the child as a whole.

Keywords: speech therapy, speech disorders, dyslalia, preschooler, preschool institutions, speech therapist.

\section{Introduction}

The problem of speech defects is one of the most important in preschool education, because of the importance of speech in the psychosocial development of the child. After all, people with various speech disorders occur quite often. And the development of society by information type, instability and unpredictability of this process can both influence the process of socialization of the child in the preschool age and exacerbate emphasize the problem of speech pathologies in children. Statistics from the last decades show that the number of children with speech problems had increased to $40-50 \%$ of the total number of preschool and primary school children, while by the middle of the twentieth century the number of such children did not exceed 17\% (Lysenko, \& Kaminska (2018), Konoplyasta, \& Galuschenko (2013)). However, it is very difficult to imagine a proper level of not only the communicative but also the vital competence of a person without their mastery of speech.

Scientists had proven the importance of early identification of problems in the speech development of the child for the success of its correction and compensation, to prevent both the difficulties of studies the child in school, and in communication with coevals and adults. The success of early diagnosis and correction of speech disorders in children may depend to a large extent on the presence of a qualified specialist in the institution of 
preschool education (IPE) - a logopedist, able to operatively notice a possible problem, determine the form of speech violation and help the child with a speech disorder to deal with their problem. Logopedic's diagnostics at the practical level helps to rightly solve the issue of selecting children and completing of the special groups or educational institutions for children with speech impairments, as well as a prerequisite for finding effective, differentiated pathways to speech therapy influence. Preventive education and upbringing of preschool children with speech impairments and directly speech therapy with children with speech impairments of older preschool age, especially with the general underdevelopment of speech in the conditions of speech therapy of IPE group, are of particular importance for the preparation of a child to education school.

It should be noted that speech is the process of mastering and using of certain language by the person in communication with other people and in the process of speech activity. Violations in speech are defining as deviations in the speech of a person, who speaks, from a language norm, adopted in a certain linguistic environment, caused by a disorder of the normal functioning of psychophysiological mechanisms of speech activity (Volkova, 2007).

It's interesting that a great number of scientific psychological and pedagogical and medical literature, fundamental and versatile studies had devoted to the problems of speech development, speech disorders, to peculiarities of the logopedist work (R.Ye. Levina (1963), I.A. Zimnaya (2001), N.V. Nishchev (2001), V.M. Androsov (2004), T.N. Volkovskaya, \& G.H. Yusupova (2004), T.R. Kislov (2005), I.A. Glystin (2006), I.H. Dmitriyenko, \& L.O. Fedorovich (2006), Ye.F. Arkhipova (2007), V.A. Kalyagin (2007), T.V. Ovchinnikov (2008), T.B. Filicheva, G.V. Chirkin, \& T.V.Tumanov (2008), G.V. Chirkin, \& A.V. Lagutin (2008), T.N. Volkovskaya (2010), V.A. Kislichenko (2012), S.Yu. Konoplyasta, \& T.V.Sak (2012), O.V. Vinokurova, \& S.M. Vinokurova (2014), N.M. Turenko ( 2014), M.A. Polshina, \& N.M. Suslova (2015), V.I. Galushchenko (2016), N. Volik (2017), Yu.V Ribtsun (2018), L.I. Trofimenko (2018) and others that substantiate the importance of this research to certain degree. Although the problem of speech underdevelopment in children has been thoroughly developing and covering by many scholars since the 50 s-60s of XX century, but, it remains relevant due to objective circumstances. Psychological features of children with language defects, who are deprived of adequate communication with their coevals because of their speech disorders, in general, very rarely get into the field of vision of scientists who do not always notice the "patient» himself and don't pay attention attention to his well-being beyond the 
«desease» and the process of «treatment», which substantiates the relevance of our research. In particular, L.I. Trofimenko emphasizes the «least studied is the aspect of personal development» (Trofimenko, 2018) of children with speech disorders too.

The purpose of this article is to theoretically analyze the problem of speech development disorders and to empirically examine the influence of speech disorders on the personal development of a child in older preschool age.

The work is testing the hypothesis that specific emotional and personal features are inherent to preschool children with speech disorders.

\section{Research methods}

The system of the methods of scientific search had used in the work: theoretical: theoretical and methodological analysis, comprehension and generalization of the provisions of scientific psychological and pedagogical literature on the topic of research; empirical: test «Cactus» of M.A. Panfilova, projective technique «I am in kindergarten» (of M. Bykova, \& M. Aromshtam), the technique of research of the self-assessment by T.V. Dembo and S.Ya. Rubinshtein in the modification of A.M. Prikhozhan, a technique for defining of the level of development of the communicative sphere of preschool children, the technique «Investigation of individual characteristics of the child»; method of processing the results of the study: Mann-Whitney U-test.

\section{Theoretical aspects of the problem of speech development disorders}

\section{Speech disorders at preschool age and their causes}

O. Lysenko and O. Kaminska define the concept of speech disorder as follows: it is «deviation from the norm (disorder) caused by changes in the structure or operation of the language system or delay of the overall mental development of the child in the process of functioning of mechanisms of speech activity» (Lysenko, \& Kaminska, 2018, p.170). Speech disorders can affect various components of speech activity. Some of them relate only to pronunciation and are expressing in violation of its expressiveness without any concomitant attendant phenomena, others are manifesting in defects of pronunciation and reading and writing disorders. Incorrect pronunciation, a limited reserv of words, not grammatically worded sentences accompany the process of normal mastering of native speech to a certain age. The defects of speech are regarded as violations of speech only from a certain age.

Psychological and pedagogical criteria allow to differentiate speech disorders on the following features: 
- Violation of the form of speech (oral or written);

- Impaired type of the speech activity in accordance with forms (for oral speech - impaired speaking or hearing, for written - reading or writing);

- Disturbed operations that design the statements at certain stages of speech production or perception;

- Impaired means of design of expression (Kuznetsova, Peresleni, \& Solntseva, 2002).

The psychological and pedagogical classification of speech disorders of R.Ye. Levina, who distinguishes two groups of such violations: disorders of linguistic means of communication (operating side - lack of verbal means because of their bad formation: general underdevelopment of speech dysarthria, alalia, rhinolalia; phonetic-phonematic underdevelopment dysarthria, rhinolalia, or disorder - afasia) and violation of the applying of linguistic means of communication (Levina, 1963) is the basic and most popular in the scientific literature.

R.Ye. Levina and the staff of her laboratory had developed out the periodization of the manifestations of general underdevelopment of speech (GUS): from complete absence of linguistic means of communication to the expanded forms of coherent speech with elements of phonetic-phonematic and lexico-grammatical underdevelopment. She and other scholars had identified three levels of language development that reflect the typical state of speech components in preschool children with GUS (Levina, 1963). The transition from one level to another is determining by the emergence of new language opportunities, increasing of the language activity, changing the motivational basis of speech and its subject-meaning content, mobilization of the compensation fund.

Scientists identify the following major causes of speech disorders in children: lack of communication with adults, who will attentively monitoring and correcting the child's speech; problems in the development and functioning of the motor sphere of the preschooler; speech disorder as a component of a more serious defect in the child's development, delay in speech development as part of the delay in the overall development of the child's nervous system (Lysenko, \& Kaminska, 2018, p. 171).

According to T.M. Volkovskaya, the main contingent of modern speech therapy are the following three groups of logopaths:

- Children with speech disorders, caused by organic and functional deficiency of the central and peripheral nervous system;

- With lack of linguistic competence as a result of the absence of full value linguistic environment; 
- With communicative disorders caused by personality traits (Volkovskaya, 2010, p. 70).

However, the scientist also offers her own, psychological classification of types of logopaths, based on the correlation of components (operational and motivational) in causing communicative difficulties, where the main indicator is «level of quality of communication«: 1) with communicative disorders, based on the lack of the formation of means of communication (general underdevelopment of speech: dysarthria, alalia, rhinolalia; phonetic-phonemic underdevelopment: dysarthria, rhinolalia); 2) with communicative failure because of means of communication disorders (aphasia); 3) with direct communication disorders (primary communication's): stuttering, voice disturbance; 4) with a combined type of communicative disorders (general underdevelopment of speech, stuttering; phonetic-phonematic underdevelopment, stuttering; violation of the pace of speech, etc.) (Volkovskaya, 2010, p. 72).

\section{Psychological pequliarities of preschoolers with speech defects}

Scientists focus their attention mainly on the disorders in the cognitive sphere of the child: mainly on the specificity of their perception and thinking, analyzing the psychological problems, which happen to children with speech defects. Thus, L.I. Trofimenko notes that «in most children with severe speech impairments we can observe the limitation of thinking processes, speech generalizations, specific difficulties in mastering reading, writing», which may further complicate the learning of school knowledge by children (Trofimenko, 2018). M.O. Polshina adds that such disorders «negatively affect the child's mental development as a whole, reflect on his or her activity and behavior ... on mental development, especially on the formation of higher levels of cognitive activity, which is caused by the close interconnection of speech and thinking and the limitation of social contacts in the process of which the knowledge of the surrounding reality» by child is awaring (Polshina, 2015).

T.S. Ovchinnikova studied attention of children with speech disorders. She was able to identify the features of this process and their role in the productivity of children's activity, as well as during prolonged mental amount (Ovchinnikova, 2008). She notes insufficient stability of attention, increased distraction, impulsivity, general disorganization of the motor sphere and behavior of such children. In children with a predominance of excitement and a low ability to self-regulation, the percentage of errors in the fulfilling of tasks is greater than in inhibited ones. When all properties of attention: concentration, switching, distribution, volume, and stability are 
reducing in general, the combination of these indicators in children with different degrees of expression of speech impairment may differ significantly.

While valuable, in our opinion, is N. Volik's remark that «configurability of teachers and parents first and foremost to the development of thinking leads to the neglect of the emotional and spiritual component of a child's personality, transforming it into a secondary value» (Volik, 2017). This is the absence of a compex vision of the problem (except gaps in the cognitive sphere of personality, there are problems in the personal sphere and communication of the child, which «negatively affects the formation of knowledge of children about themselves and other people, the neighbouring world on the whole». In a result - the process of entrance of the kid to everyday «norms of social life» is complicating) (Volik, 2017).

The opinion of T.M. Volkovskaya that «disorders of the cognitive and personal spheres can have different psychological structures and be closely related to the degree of expressiveness and nature of speech disorder (Volkovskaya, 2010, p. 69) is worthy our attention. O.V. Vinokurova and S.M. Vinokurova also emphasize that different speech disorders in children may have different effects on the child's personality and behavior (Vinokurova, \& Vinokurova, 2014). So, children are awaring of their dyslalia «as a result of the parents' comments» (Filicheva, Chirkina, Tumanova, Mironova \& Lagutina, 2008). They show shyness, «become insociable, unsure of their strengths and possibilities», and as a result, may develop such character traits as seclusion, negativism, with lack of communication. Scholars also confirm that speech disorders contribute the development of a child's negative character traits, such as shyness, indecision, and arising of the inferiority complex (Trofimenko, 2018; Lysenko, \& Kaminska, 2018).

Not less interesting is the idea of scientists that the development of a preschooler's personality is causing not only by speech disorders, but also by the fact that the child begins to realize their defect, how it is perceiving by others, and tries to adapt to the situation that leads to the emergence of «secondary» disorders: psychological protective mechanisms, using by child, can influence the formation of their character and personality as a whole (Trofimenko, 2018). O.V. Vinokurova and S.M. Vinokurova added that, awaring of their defects, children can «refuse to tell poems, try to answer in one word, quietly, or avoid communication», «masking their defect» (Vinokurova, \& Vinokurova, 2014).

However, the problems of the children with speech disorders rise in the communicative process first of all: they try to avoid it, that causes «underdevelopment of communication means - two types of speech dialogical and monologic». Such children exhibit negativity in statements, 
avoid contact, and are «poorly oriented in communication's situation» (Volik, 2017).

According to T.N. Volkovskaya, personality and communication disorders in children with speech impairments depend on the group of disorders. In the case of a violation of the operative side of speech, they can be as follows: difficulty in making contact, especially with strangers; inability to orientate in the communication situation; failure to adequately transfer information and choose appropriate means of interaction; inability to listen; inability to overcome barriers in communication. Whereas, when the main ones are motivational disorders, the personal impairment is the difficulty in using the means of communication: lack of need to communicate, isolation, lack of initiative to begin the communication; inability to empathy and decentration (Volkovskaya, 2010).

\section{Interaction of the educator and speech therapist in a preschool institution}

The professional activity of logopedist is to provide logopedic and medical and psychosocial help to persons with speech disorders, which is providing by a complex system of corrective work, in particular, a system of studies to eliminate violations, first of all, of oral speech, etc. Therefore, a logopedist must have knowledge not only of linguistics, age psychology, but also of medicine - knowledge of anatomical and physiological mechanisms of speech, structure of the speech apparatus and the process of its functioning, which allows to distinguish between pronunciation in the norm and with disorders and to determine the paths of speech therapy (Volkovskaya, \& Yusupova, 2004).

The logopedist examines the children in the first two weeks of their stay in the speech therapy group of the children's institution. The main tasks of the examination are:

- Study the conditions of education and development of the child (communication with adults and coevals) on the basis of conversation with parents and analysis of doctor's documentation;

- Identification of the level of development of leading activity (play, drawing, constructing, elements of work) and its assessment in accordance with age standards (together with the tutor);

- Identification of the characteristic traits of the emotional-personal and cognitive spheres, general mental development of the child;

- Assessment of the status of coherent speech in terms of its lexical and syntactic design; 
- Determination of the degree of mastery of the child by the components of the speech system (Dmitriyenko, \& Fedorovich, 2006).

The speech therapist establishes contact with the child, directs communication during the conversation with they. He asks the kid questions that find out his or her outlook, interests, relationships with surrounding, whether the child is orienting in time and space or not. The questions are asking in such a way that the answers will be deploying. This conversation gives the first conclusions about the speech of the child, determines the direction of further examination of different sides of their speech (Garkusha, 2002).

It is necessary to the logopedist to find out in all speech disorders: does the child know about their defect, how does they react to it; Is they experiencing difficulties in communicating with others or no; how they interacts with close, familiar and unfamiliar adults, with friends in kindergarten, in the yard; child's behavior at home. He has to elucidate what the parents' complaints are: whether they are disturbed by the child's incorrect pronunciation of some sounds, grammatical design of the speech, insufficient vocabulary, errors in the construction of sentences, rate of speech, etc. (Volkovskaya, 2003).

Depending on the level of communication disorders and the attitude to speech defect, preschoolers with speech impairment are divided into three groups:

- Children are not concerned about their own speech defect, so there is no difficulties with speech contact; they actively interact with adults and coevels, using non-verbal communication;

- Children have difficulties in the process of establishing contact with their environment, they do not seek communication, avoiding situations, in which the speech is required. In the process of the game they resort to non-verbal means of communication, acutely experiencing their speech defect;

- These children experience speech negativism - they refuse to communicate, are closed, can be aggressive, have low self-esteem (Vinokurova, \& Vinokurova, 2014).

The results of a complex study of a child with speech impairment are summarized in the form of a logopedist's conclusion, indicating the level of speech development of the child and the form of speech defect. A complex of correctional training of the child is made on this basis.

Carrying out the entire complex of correctional training in speech therapy requires a combination of special studies of correction of the 
deficiencies of speech with the fulfillment of the joint program requirements of the children's institution. For the speech therapy groups of kindergarten a special regime of the day is developed, which is different from the usual one. It is provided for speech therapist to held frontal, group and individual classes. At the same time, the class schedule includes time for studies in a typical complex program for preschool children. In addition, hours are allocated in the evening for the educator to work with subgroups or separate children with speech correction or development. The caregiver plans his work taking into account the requirements of both the typical complex program and the language abilities of the children and their promotion in the master of the corrective program, which is implemented by the speech therapist in accordance with the nature of the language violation of the child.

In this regard, there is a need to ensure interaction, continuity in the work of the caregiver and speech therapist in the speech therapy group (Kislova, 2005; Matrosova, 2007; Chirkina, \& Lagutina, 2008). The tutor should know the basic directions of the correction program, age and individual peculiarities of the formation of speech of preschool children, understand the peculiarities of pronunciation and of lexical and grammatical side of the speech and take into account the language abilities of each child in the process of educational and out of educational activities.

The educator together with the logopedist, plans studies on the development of speech, familiarization with the outside world, preparation for learning reading and writing and motility of the hand in writing. The continuity in the work of speech therapist and educator involves expects not only joint planning, but also the exchange of information, discussing the achievements of children, both in language and in other studies.

The caregiver of the logopedic group performs in addition to generally educational a number of corrective tasks, the essence of which is to eliminate deficiencies in the sensory, affective-volitional, intellectual spheres of the child due to features of the speech defect (Zimnaya, 2001; Hlystina, 2006; Kalyagin, \& Ovchinnikova, 2007). During this the educator pays its attention not only to the correction of existing defects in the development of the child, to the enrichment of ideas about the environment, but also to the further development and improvement of the activity of the preserved analyzers. The basis for favorable development of the compensatory possibilities of the child, which ultimately influence the effective mastering of the language is creating by this.

Compensation for language underdevelopment of a child, their social adaptation, and preparation for further education at school dictate the need to mastering, under the tutor's guidance, those kinds activities that are expected by programs of mass-kindergarten of the general developing type 
(Derzhavna nacionalna, 1993; Programa rozvytku, 2004). The educator should pay particular attention to the development of perception (visual, auditory, tactile), processes of memory, accessible forms of visual-shaped and verbal-logical thinking, motivation of game and educational activity.

An important aspect of working in the speech therapy group is the development of cognitive activity and cognitive interests in children. At the same time it is necessary to take into account a peculiar lag in the formation of cognitive processes as a whole, which is formed in children under the influence of linguistic underdevelopment, narrowing of contacts with others, wrong methods of family upbringing and other reasons.

The correct, pedagogically justified interaction between the caregiver and speech therapist, unites their efforts in the interests of correcting speech in children, and its basis core is to create a supportive, emotionally-positive environment in the speech therapy group. The psychological atmosphere in the children's group strengthens the children's belief in their own possibilities, allows to smooth out the negative experiences related to linguistic deficiency, to generate interest in the lessons. For this purpose, the educator, as well as the speech therapist, must have knowledge in the field of psychology and physiology of preschool children. They need to be able to understand the various negative behaviors of children, to notice in time the signs of increased fatigue, passivity and slugginess. Correctly organized psychological and pedagogical influence of the caregiver in most cases prevents the emergence of persistent undesirable deviations in the behavior of the child with speech disorders, forms a friendly, socially acceptable relationship in the speech therapy group.

In many cases, the work of an educator of language development precedes to logopedist studies, prepares children for the perception of material at future logopedist studies, providing the necessary cognitive and motivational basis for the formation of language knowledge and skills. In other cases, the caregiver focuses his attention on consolidating the results achieved by children in logopedist's lessons.

The organization of mobile games for children with language disorders occupies the special place in the work of the tutor, since the children of this category are often somatically weakened, physically unsteady, quickly tired, are passive and unsociable. Planning work on the organization of play activities, the educator must clearly understand the real of the physical possibilities of each child and differentially select mobile games. Such games, which usually form the part of physical training and musical classes, can be held on a walk, on holiday matinee, during an hour of entertainment. 
It is necessary to combine mobile games with other kinds of activities of children. Mobile games simultaneously help to shape the language successfully. They often have by-words, four-verses; they can precede to the counters for choosing the host of the game. Such games also promote the development of a feeling of rhythm, harmony and coordination of movements, positively affecting the psychological state of children (Selivestrov, 2007).

The work of a tutor in teaching children a story-role game is also a necessary element of pedagogical activity in the logopedical group. In storyrole games, the educator activates and enriches the children's dictionary, develops coherent speech, teaches the ritual interaction in familiar to the child social and everyday situations (physician's reception, shopping at the store, traveling in transport, etc.). Story-role games promote the development of the communicative language skills; stimulate sociability of children, bringing up social habits and skills (Schwayko, 2008).

Not only the interaction between educators and logopedist, but also the interaction between teachers and parents, had to be organized in the logopedist group. And an atmosphere of friendly and attentive attitude to children, the desire to create comfortable interaction in the process of correctional work must be present (Povalyaeva, 2002). So, «systematic homebased lessons with a child will help to correct existing violations of pronunciation of sounds and open they the path to successful school education» (Ribtsun, 2018).

V.I. Galushchenko believes that the modern personal-oriented educational and correctional process in preschool institutions «is based on interactive technologies, introduction of new, innovative, nontraditional forms of work, with the involvement of ... various professionals, who work under a single ... scheme» (Galushchenko, 2016). While the effect of their using to children, who have a developmental deviations in speech, depends primarily on the professional competence of the teacher, his / her ability to use «untraditional technologies in each child's educational system, creating ... motivation and psychological comfort» for them, and giving «freedom to choose forms and means of activity» (Androsova, 2004).

The innovative technologies are the «new methods, techniques, means, introduced into practice that are more effective than existing ones and are the result of the educator's intellectual activity» (Turenko, 2014). Scientisn N.M. Turenko notes that the new technologies that can be applied in the corrective process for children with speech disorders are: arttherapeutic technologies (music therapy, fairy-tale therapy, puppet-therapy, etc.); modern technologies of finger and logopedic massage (massage with stones (stone therapy), pouch with herbs); modern technologies of sensation 
education; cryotherapy (in the format of games with snow and ice); «su-jok» therapy - massage from the palms / feet of the child with the help of various devices (massage sticks, rings, «hedgehogs», etc.); information technologies (language programs, correctional video games) (Turenko, 2014).

M.A. Polshina and N.M. Suslova notice that logopedist not only «instals sounds», but also develops the mental functions of the child, its cognitive processes, opening to the kid «unlimited possibilities for communication, he is an original guide of a small person to the various world of human relationships», helping the child to believe in their strength (Polshina, \& Suslova, 2015).

The process of correction of speech defect consists of the following steps:

1. Diagnosis of the level of language development with futher establishing of logopedist conclusion.

2. Planning the work with the children on the basis of a differentiated approach, depending on the structure of the language defect and taking into account the accompanying secondary disorders and the subsequent implementation of the work plan.

3. Tracking the dynamics of language development through a comparison of introductory and repeated (final) diagnostics (Nischeva, 2001).

In the case of correction of language disorders, the most relevant become the understanding of children's behavior in the process of interaction and communication. It is possible to distinguish three sides of behavior of children with speech defects (to which neurological symptoms have not joined) (Kalyagin, \& Ovchinnikova, 2007): individual tactics of adaptive behavior, formed on the basis of hereditary predisposition and experience of children; the presence of non-adaptive behavior forms; peculiarities of behavior in different situations (in the coeval group, when communicating with the logopedist, in the family).

\section{Method}

\section{Participants}

To achieve the goal of the work and to test its hypothesis, we had conducted an empirical study.

The sample consisted of 33 persons - preschool age children (5,5-6 years), including 15 girls, 18 boys. The sample was divided into two groups the first (I, $\mathrm{n}=18: 10$ girls, 8 boys), which included children from a typical kindergarten group and the second (II, $\mathrm{n}=15: 10$ boys, 5 girls), composed by 
preschoolers with speech development disorders, mainly with dyslalia, logopedic group of the institution of preschool education № 33 - «Dwelling of talented» of the Chernivtsi. It should be noted that phonetic speech impairment (dyslalia) is a violation of pronunciation of sounds with normal hearing development and preserved innervation of the lanquage apparatus. These violations are manifesting in the defects in the reproduction of the sounds of the mother tongue: their distorted pronunciation, the replacement of some sounds with others, the mixing of sounds and, more rarely, in their omission (Volkova, 2007).

\section{Materials and procedure}

We used the following psychodiagnostic tools in the study: the test «Cactus» by M.A. Panfilova (Projective methodology, n.d.), projective technique «'m in kindergarten» (by M. Bykova, M. Aromstam) (Test «I am in kindergarten», n.d.), the technique of self-assessment by T.V. Dembo and S.Ya. Rubinstein in the modification of A.M. Prikhozhan (Self-assessment study, n.d.), the technique for identifying the level of development of the communicative sphere of preschoolers (Method of definition, n.d.), the technique «Investigation of individual peculiarities of the child» (Questionnaire for, n.d.).

Test «Cactus» by M.A. Panfilova is fixed to identify the state and peculiarities of the emotional and personal sphere of the child, to diagnose the presence of aggression, its direction and intensity, as well as such personal characteristics as impulsiveness, self-centeredness, dependence (uncertainty), demonstrativeness (openness), carefullness, anxiety, optimism, femininity, extraversion, introversion, the aspiration for home protection and the pursuit of loneliness.

At the beginning of the study, children were given a piece of paper and colored pencils. Then an interesting task - to draw a cactus, which they imagine - was offered to them. The children was given as much time as they needs.

The projective technique «I am in kindergarten» by M. Bykova, \& M. Aromshtam is used to test-up the psychological comfort of a child's staying in the kindergarten group. It should be noted that just in the kindergarten that the child of preschool age is staying for the most time. And the situation of upbringing and communication in the kindergarten itself is most influencing by the formation of their adequate self-acceptance and self-attitude at this age. Therefore, not only the parents but also the teacher, the educator need to understand how comfortable the child feel themselves in the kindergarten group among other children. We asked the 
children to make an interesting drawing on the subject «I am in my kindergarten group»».

Time for this task was not limited.

We didn't commented on the actions the children and did not directly or indirectly suggest them what elements could be included in the drawing during the test painting.

The technique of self-assessment by T.V.Dembo and S.Ya. Rubinstein in the modification of A.M. Prikhozhan is based on direct assessment (scaling) of a number of personal qualities by children.

We asked children to mark with certain signs (for example, a dot) on the vertical lines the level of the development of these qualities (indicators of themselves. The instruction was given to all children at the same time. We informed the examinees that each person assesses their abilities, possibilities, character, etc. The extent, to which each quality is developed, can be conditionally depicte by a vertical line, where a lower point means the poor (bad), lowest development of the quality and a higher one means the highest, best level. The children were offered seven vertical lines, explained what each one meant: health; intelligence/abilities; character; authority in coevals (classmates); ability to do a lot of things with their own hands - skillful handles; appearance; self-confidence.

We asked the children to mark, with the dash or dot on each line, how they evaluated their development of this quality at this point in time (where they would put themselves).

Each participant was gave a form, which depicted seven lines, the height of each - $100 \mathrm{~mm}$, indicating the upper, lower points and the middle of the scale. In this case, the extreme points of the scale are marked by significant lines (hyphen), and the average - barely noticeable point.

The technique was carried out frontally - with a whole group of children. Preschoolers filled the scales gradually, we checked the correctness of the first one. It was necessary to make sure that the children correctly understood the instruction to the procedure. After that, the examinees worked independently. The time gave for filling the scales is 10-12 minutes.

Each answer can be expressed in points or levels, when processing the results of the technique. As noted earlier, the length of each line is 100 $\mathrm{mm}$, so accordingly we measured quantitatively how far from the beginning of the line the mark was placed by the child. The level of self-esteem of the respondents was determined in such a way: a segment of 10-20 mm meant a low level of self-esteem of the child, 30-40 - understated, 40-50 - average, 60-70 - higher than average, high, 80-100 - too high, very high.

The technique for detecting the level of development of the communicative sphere of preschoolers was used by the educators (they, 
according to this technique, assess the communicability of children) during joint children's games. The more active child in the communication with coevals has the higher level of development of their communication sphere. caregivers were able to put each of preschoolers from 2 (closed child, does not respond to games of coevals) to 10 points (overactive child, that is, constantly encourages coevals to games and communication, does not leave them in peace) assessing the communication skills of them.

The technique «Investigation of individual peculiarities of the child» is intended to determine the level of anxiety of the study participants. The technique contains 20 statements regarding the behavioral characteristics of the child. Educators of researched groups answered the questions of the technique. In that case, if the statement of the technique is considered true for a particular child, characterizes them, it was evaluated by plus, if do not by minus.

As a result, the number of positive marks (points) is added to obtain an overall indicator of the child's anxiety: 15-20 points - high anxiety; 7-14 points - average anxiety; 0-6 points - low anxiety level of preschooler.

\section{Results}

According to the technique «Cactus» by M.A. Panfilova the following results were obtained (given here and in other techniques, with differentiation of three levels of manifestation diagnosed signs, the results of two groups (I and II sequentially) in comparison of high and low levels of manifestation of indicators): high-level aggression is shown in the drawings of $55.55 \%$ children of group I and of $66.67 \%$ - group II; of low (absent) at $44.44 \%$ and $26 / 67 \%$ examinees; impulsiveness was found in the drawings of $44.44 \%$ and $73.33 \%$ of children, was absent - in $55.56 \%$ and $20 \%$ of study participants; egocentrism is characteristic of $33.33 \%$ and $80 \%$ of preschool children, and is not inherent to $61.11 \%$ and $6.67 \%$ of researched; the majority of examinees are dependent - 66. 67\% and 60\%; do not demonstrate this quality of $33.33 \%$ and $26.67 \%$ of children; $44.44 \%$ and $53.33 \%$ of preschoolers showed demonstrability, but in the rest (of both groups) it was absent; images of $27.78 \%$ of grouop I are optimistic; this quality is not showed by the rest of this sample and in the sample II; anxiety is inherent in $66.67 \%$ and $33.33 \%$ of preschoolers; it is absent in $11.11 \%$ and $53.33 \%$ of the sample; extravertion is indicated in $61.11 \%$ of sample I; in sample II these indicators were $13.33 \%$ and $86.67 \%$; the aspiration of home protection is manifesting in the most preschool children $-66.67 \%$ (sample I) and $86.67 \%$ (sample II); independence - in $44,44 \%$ and $13,33 \%$ of children. 
According to the results of the projective technique «I am in kindergarten» we found out: almost all children in the drawings painted themselve $-94.44 \%$ (sample I) and $100 \%$ of children (sample I), $83.33 \%$ and $46.67 \%$ of preschoolers were positive in their drawings; $11.11 \%$ and $6.67 \%$ of the children drew other children near them; no child in their drawing depicted a caregiver; toys represented $44.44 \%$ of children's drawings of sample I; the tone of colors is positive in $27.78 \%$ and $26.67 \%$ preschooler's drawings - in the first and second groups, negative - in $44.44 \%$ and $53.33 \%$ of children's drawings; according to the overall estimation, 5.56\% / 53.33\% of preschoolers (samples I and II) have a negative attitude towards kindergarten, $83.33 \%$ / $6.67 \%$ - positive, $11.11 \%$ and $40 \%$ - ambiguous.

Application of Dembo-Rubinstein's self-assessment research technique in modification of A.M. Prikhozhan discovered the following results:

- In indicator of health, sample I: $61.11 \%$ of children have low levels of self-esteem, $22.22 \%$ - below average, $11.11 \%$ - average, $5.56 \%$ - high; sample II: $66.67 \%$ examivees had above the average level of self-esteem and $33.33 \%$ - the average level of self-esteem;

- Intelligence/abilities indicator, sample I: $55.56 \%$ of respondents showed low, 38.89\% - average, 5.56\% - overstated; sample II: $66.67 \%$ above average and $33.33 \%$ - average level of self-asteemation;

- Character scale, sample I: $55.56 \%$ of respondents demonstrated low, $22.22 \%$ - below average, $11.11 \%$ - average and high self-esteem; in sample II: $46.67 \%$ - average, $53.33 \%$ - above average self-esteem;

- Self-esteem of authority of children among peers, sample I: $66.67 \%$ of children had low, $22.22 \%$ - average, $5.56 \%$ high and below average levels of self-esteem; sample II: $60 \%$ examinees had above average, $40 \%$ average indicator's level;

- The skillfulness index, sample I: 50\% showed low, 27.78\% average, $11.11 \%$ - high and below average level of self-esteem; sample II: in $66.67 \%$ of preschoolers - average, in 30\% - above average level of selfesteem;

- «Appearance» indicator, sample I: $55.56 \%$ children had low selfesteem, $22.22 \%$ - average, $16.67 \%$ - high, $5.56 \%$ - below the average selfesteem; in sample II: $60 \%$ had above average, $40 \%$ - average self-esteem;

- Indicator - self-confidence, in sample I: $61.11 \%$ of children showed low, $16.67 \%$ - below average, $11.11 \%$ - overestimated and average levels of self-esteem of the study participants; in sample II: $60 \%$ - above average, $40 \%$ - average level of self-esteemation;

- In general, low self-esteem prevailed in 50\% examinees of sample I; other $16.67 \%$ of preschoolers have average and below average levels of self- 
esteem; $11.11 \%$ of children have above average self-esteem, $5.56 \%$ have inadequate high self-esteem; in sample II: $60 \%$ of preschool children had above average, $40 \%$ - average level of the self-esteem.

According to the technique of detecting the level of development of the communicative sphere in preschoolers, we obtained the following data: in $61.11 \%$ and $33.33 \%$ of preschoolers of the first and second samples - the average, in $38.89 \%$ and $26.67 \%$ - high, in $40 \%$ of children of sample II had a low level of communicability's development.

Questioning the educators of groups, using the technique of «Investigation of individual characteristics of the child» showed the following levels of anxiety of the examinees childs: in $77.78 \%$ of the sample I - low level of anxiety, in $22.22 \%$ - average, mean - M=3.06 points; in $86.67 \%$ of the sample II - low level of anxiety, in $13.33 \%$ preschoolers average level of anxiety, mean $-\mathrm{M}=1.6$ points; there are no anxious children in the samples.

The computerized statistical analysis of the results of the study, using the Mann-Whitney $U$ testified the statistically significant difference between the samples in such indicators: self-esteemation of health $(\mathrm{U}=29.000$; $\mathrm{p}=0.000)$, of intelligence/abilities $(\mathrm{U}=38.500 ; \mathrm{p}=0.000)$, of character $(\mathrm{U}=49.000 ; \mathrm{p}=0.002)$, of authority among peers $(\mathrm{U}=34.000 ; \mathrm{p}=0.000)$, of the ability of preschooler to do something with own hands ( $\mathrm{U}=61.500$; $\mathrm{p}=0.008)$, of their external appearance $(\mathrm{U}=73.000 ; \mathrm{p}=0.024)$, selfconfidence $(\mathrm{U}=46.500 ; \mathrm{p}=0.001)$ of the overall self-esteemation $(\mathrm{U}=58.500 ; \mathrm{p}=0.006)$ and communicability $(\mathrm{U}=64.500 ; \mathrm{p}=0.018)$.

\section{Discussion}

It is necessary to carry out the detection and elimination of speech disorders in the early stages of age development due to the fact that correct speech is one of the important prerequisites for the further of full value development of the child, the process of they social adaptation.

Deviations in the development of speech reflecting on the formation of the entire mental life of the child. They complicate communication with others, often interfere the correct formation of cognitive processes, influence the emotional and volitional sphere of the child.

A number of secondary abnormalities that form the picture of the abnormal development of the child as a whole often arises under the influence of a speech defect: preschoolers can become overly modest and closed, show passivity, indecision and unwillingness to communicate, unstable emotions, quickly get tired; uncertainty of the child and inferiority 
complex which can influence the child's adaptive capacities, they entry into the school-based learning process, and life in general may develop.

It was found in our empirical study that, compared to children with normal speech development, kids-logopaths were much more self-centered, concentrated on themselves, introvertedly-closed and incommunicable, aspire for home protection (obviously, they felt themselves better at home, than in kindergarten) on the one hand, and ill-conceived impulsively and demonstrative, disposed to aggressive manifestations - on the other. Whereas, on the contrary, they have lack of optimism and independence. A rather contradictory is the fact (since scientists (Vinokurova, \& Vinokurova (2014) point out on manifestations of anxiety as a peculiatity of preschoolers with speech disorders) of the low level of anxiety of children with speech defects, even compared to preschoolers with appropriate to age speech development. This is confirming by the results of another technique (that is, it is not accidental too), however, the difference between samples on this trait is not statistically significant. We can suppose that the situation is explaining by the attentive, with understanding and sympathy attitude to children both in the family and in the special kindergarten group (parents and caregivers), by a positive atmosphere that prevails both in the families of children-logopaths, and in the institution of preschool education, visited by preschoolers, on the one hand, and relatively small level of speech defect of children - on the other. So, V.A. Kyslichenko emphasizes that education and upbringing of a child with speech disorders «can be successful only if educators and parents will become equal partners», with joint aspirations, goals and ways of their achieving in the educational process (Kyslichenko, 2012, p.367).

It is not accidental that the self-esteem's of children-logopaths (and belief in themselves) by all indicators of the technique, including «health», are statistically significantly higher than of children with normal speech development. This, however, does not exclude a sufficiently contradictory perception of the kindergarten by these preschoolers, which is manifesting in the unacceptability of the educator and lack of communication and joint games with peers, unlike children with adequate speech development, who have predominantly positive attitude to the kindergarten, in spite of their misunderstanding by their educator. So, L.I. Trofimenko notes that such a child in the institution of preschool education may give in to mockery, grievance, and educators are not inclined to involve they in joint games. As a result, the child «closes in outself» and moves away from the children's group, without feeling equal to other children (Trofimenko, 2018 ). And O.V. Vinokurova and S.M. Vinokurova are emphasize that children with speech pathology are silent, «ashamed to talk ... have no desire to attend 
kindergarten, and then - the school» (Vinokurova, \& Vinokurova, 2014). We can assume that to normaly communicate with peers and the educator to such children is hampered by the lack of communication skills (L.I. Trofimenko (2018) is emphasizing this) and unsufficient development of the communication sphere as a whole, which reduces their desire and willingness to communicate (statistically significant of this indicator is the advantage of preschoolers with normal (age-appropriate) the speech development.

\section{Conclusions}

In conclusion, we should note that the study of the basics of speech therapy is important and necessary for all staff of children's, especially preschool, institutions. A significant percentage of speech disorders are detected in preschool age, as this age is a sensitive period for speech development. And timely detection of these disorders facilitates to their faster overcoming, prevents the negative impact of language disorders on the formation of personality, its acquisition of knowledge and expression of their creative abilities, and on the mental development of the child as a whole. Therefore, we can assume that speech therapy and speech psychology take an important part in solving general pedagogical tasks of preschool institutions.

\section{References}

Arhipova, E.F. (2007). Speech therapy work with young children. Moskow: AST: Astrel'.

Bogush, A.M. (Ed.). (2001). Linguididactics in modern educational institutions. Odessa: PNC APN Ukrai'ny.

Chirkina, G.V., \& Lagutina, A.V. (2008). Planning of the speech therapy classes in a group of children with FFD. Vospitanie i obuchenie detej s narushenijami razvitijaEducation and training of children with disabilities, 4, 14-20.

State national program «Education. Ukraine of the XXI century». (1993). Osvita, 44-46, 5.

Dmitrienko, I.G., \& Fedorovich, L.O. (2015). Map of the speech examination of a child of preschool age with speech disorders. Poltava.

Filicheva, T.B., Chirkina, G.V., Tumanova, T.V., Mironova, S.A., \& Lagutina, A.V. (2009). Programs of the pre-school institutions of compensating type for children with speech disorders. Moskow: Prosveshhenie.

Galushhenko, V.I. (2016). Application of innovative technologies in speech therapy correction work with children with speech disorders. Aktual'ni pytannja korekcijnoi' osvity - Topical issues of correctional education, 7. http://aqce.com.ua/download/publications/45/42.pdf/

Garkusha, Ju.F. (2008). Correctional and pedagogical work in preschool institutions for children with speech disorders. Moskow: TC «Sfera», NII Shkol'nyh tehnologij. 
Glistina, I.A. (2006). Features of emotional development of preschoolers with general underdevelopment of speech. Prakticheskaja psihologija i logopedijaPractical psychology and speech therapy, 5, 30-35.

The study of self-esteem by the Dembo-Rubinstein method in the modification of A.M. Prikhozhan. (n.d.). https://www.psychologos.ru/articles/view/80844metodika-diagnostika-samoocenki-dembo-rubinstejn-modifikacia-amprihozan

Kaljagin, V.A., \& Ovchinnikova, T.S. (2007). Logopsychology. Moskow: Akademija.

Kislova, T.R. (2005). Teachers and parents about the speech development of preschoolers 3-4 years. Nachal'naja shkola: Pljus do i posle - Primary school: Plus before and after, 10, 37-41.

Konopljasta, S.Ju., \& Galushhenko, V.I. (2013). Development of sensorimotor level of speech-motor organization in older preschool children with erased dysarthria. Logopedija - Logopedics, 4, 43-48.

Konopljasta, S.Ju., \& Sak, T.V. (2012). Logopsychology. Kyiv: Znannja.

Kuznecova, L.V., Peresleni, L.I., \& Solnceva, L.I. (et al.). (2002). Fundamentals of special psychology. L.V. Kuznecova (Ed.). Moskow : Jeksmo.

Kyslychenko, V.A. (2012). Comprehensive program of speech therapy support for families raising a child with speech disorders. Zbirnyk naukouyh prac' KPNU. Serija : Social'no-pedagogichna-Collection of scientific works of KPNU. Series: Sociopedagogical., 19(1), 366-372.

http://nbuv.gov.ua/UJRN/znpkp sp 2012 19(1) 41 [in Ukrainian]

Levina, R.E. (1963). On the restructuring of the principles of analysis of speech disorders in children. Special'naja shkola - Special school, 2, 16-22.

Lysenko, O., \& Kamins'ka, O. (2018). Features of logopedic work organization with preschool children. Osvitnij prostir Ukrai'ny - Educational space of Ukraine, 13, 167-172. DOI: 10.15330/esu.13.167-172.

Matrosova, T.A. (2007). Joint work of speech therapist and educator in groups for children with speech disorders. Logopedija - Logopedics, 4, 35-37.

Method of determining the level of development of the communicative sphere in a preschooler. (n.d.). https://www.psyoffice.ru/3-0-praktikum-00027.htm

Nishheva, N.V. (2001). System of correctional work in speech therapy group for children with general speech underdevelopment. Saint-Petersburg: Detstvo-press.

Ovchinnikova, T.V. (2008). Logopedic DOP mode as a condition for effective correction of children's speech. Logoped-Logopedist, 3, 100-103.

Pol'shina, M.A., \& Suslova, N.M. (2015). Actual problems of modern speech therapy. Koncept-Concept, 08. http://e-koncept.ru/2015/15271.htm. [in Russian].

Povaljaeva, M.A. (Ed.). (2002). Correctional pedagogy. Interaction of specialists. Rostov-ondon: Feniks.

Projective technique «Cactus». (n.d.). https://studfile.net/preview/2378996/ 
Trends and Prospects of the Education System and Educators' Professional ...

Program of development, education and upbringing «Child in preschool years».

(2004). Zaporizhzhia : TOV «LIPS» LTD.

Ribcun, Ju.V. (2018). Child with speech development disorders. Kharkiv: Ranok; Kenguru.

Questionnaire for the study of individual characteristics of the child. (n.d.). https://psylist.net/praktikum/00162.htm.

Selivestrov, V.I. (2007). Games in speech therapy work. Moskow: Jeksmo.

Shvajko, G.S. (2008). Games and game exercises for speech development. Moskow: AST.

Test „I'm in kindergarten». (n.d.). https://studfile.net/preview/2378996/

Trofymenko, L.I. (2018). Features of development of personality of preschoolers with speech disorders. Teoretychne $i$ metodychne zabezpechennja navchannja ta vyhovannja osib z osoblyvymy osvitnimy potrebamy - Theoretical and methodological support for the education and upbringing of persons with special educational needs, 8, 224-229. http://lib.iitta.gov.ua/713055/1/Stattja Trofymenko.pdf.

Turenko, N.M. (2014). Nowaday developments of logopedics theory and practicals. Zbirnyk nankoyyh prac' HDU. Pedagogichni nauky - Collection of scientific works of KSU. Pedagogical Sciences, 66, 406-410. http://nbuv.gov.ua/UJRN/znppn_2014_66_74

Vinokurova, O.V., \& Vinokurova, S.M. (2014). Influence of speech disorders on the personality and behavior of the child. Naukovyj chasopys NPU. Serija 19: Korekcijna pedagogika ta special'na psybologija - Scientific journal of NPU. Series 19: Correctional Pedagogy and Special Psychology, 28, 37-41. http://nbuv.gov.ua/UJRN/Nchnpu_019_2014_28_10.37

Volik, N. (2017). Towards the problem of socialization of preschool children with speech disorders. Nankovyj visnyk MDPU. Serija: Pedagogika - Scientific bulletin of MSPU. Series: Pedagogy, 1, 26-31. http://nbuv.gov.ua/UJRN/Nvmdpu_2017_1_5

Volkova L.S. (Ed.). (2007). Speech therapy: method. heritage. Vol. 5: Phonetic-phonemic and general underdevelopment of speech: speech disorders in children with sensory and intellectual disabilities. Moskow: Vlados.

Volkovskaja, T.N. (2003). Comparative study of features of development of preschool children with the general underdevelopment of speech and with a delay of mental development. Moskow : Jeksmo.

Volkovskaja, T.N. (2010). Problems of Classification in Logopsychology. Izvestija SUNS. Serija. Filosofija. Psibologija. Pedagogika - News of SUNS. Series. Philosophy. Psychology. Pedagogy, 1, 68-73. https://cyberleninka.ru/article/n/k-voprosu-Oklassifikatsionnoy-sisteme-v-logopsihologii

Volkovskaja, T.N., \& Jusupova, G.H. (2004). Psychological assistance to preschoolers with general underdevelopment of speech. Moskow : Knigoljub.

Zimnjaja, I.A. (2001). Linguopsychology of the speech activity. Moskow : Akademija. 